\title{
NOWE STARE MIASTO W ELBLĄGU - WIELOASPEKTOWOŚĆ INTERWENCJI W OBSZARZE ZABYTKOWYM
}

WIŚNIEWSKA Katarzyna ${ }^{1}$

${ }^{1}$ Katarzyna Wiśniewska Politechnika Poznańska / Wydział Architektury / kandydatka do stopnia doktora

https://orcid.org/0000-0002-8504-7494

ABSTRAKT: Celem niniejszego artykułu jest przegląd zasad ingerencji w obszarze zabytkowym poprzez chronologiczne przedstawienie różnych koncepcji odbudowy Starego Miasta w Elblągu jako teoretycznych podstaw odbudowy oraz ukazanie przemian w podejściu do projektowania nowej zabudowy w obszarze zabytkowym.

Poprzez przykłady i określenie faz odbudowy Starego Miasta w Elblągu chciałabym poddać refleksji, czy retrowersja jest procesem dostosowującym się każdorazowo do nowych współczesnych potrzeb, czy raczej retrowersja jako autorska metoda zakończyła się w 2002 roku wraz z zaprzestaniem nadzorowania projektów przez jej autorkę i od dziewiętnastu lat obserwujemy po prostu proces budowy Nowego Starego Miasta.

SŁOWA KLUCZOWE: Nowe Stare Miasto, retrowersja, Nówka Starówka 


\section{Wprowadzenie}

Minęło prawie czterdzieści lat od sformułowania zasad retrowersji - konserwatorskiej metody odbudowy Starego Miasta w Elblągu. Autorka metody, prof. Maria Lubocka-Hoffmann w 2019 roku została laureatką nagrody ICOMOS imienia profesora Jana Zachwatowicza. W laudacji autorstwa prof. Ewa Łużyniecka napisała: Przygotowane dla Starego Miasta w Elblagu wytyczne w rzeczywistości byly nowa konserwatorska metoda odbudowy miasta historycznego, która ich autorka nazwała <retrowersją, której fundamentem jest <autentyzm>. Dla retrowersji charakterystyczne jest kształtowanie krajobrazu zniszczonego miasta lub jego części poprzez aranżowanie "nowego starego miasta” i kreowanie zbioru wartości utożsamianych $z$ wizerunkiem i atmosfera zespołów staromiejskich. Definiując retrowersję autorka metody pisze, że jest rodzajem konserwatorskiej kreacji, która respektuje historyczne uwarunkowania, lecz nie reprodukuje dawnej zabudowy, i celem której jest takie zagospodarowanie historycznej przestrzeni, aby zgodnie z zasadami konserwatorskimi spetniała współczesne oczekiwania społeczne.

W ostatnich latach podejmowane są działania mające na celu przybliżenie zasad retrowersji zwłaszcza młodszemu pokoleniu, które zastało Nowe Stare Miasto i artykułuje tęsknotę za nieznanym przedwojennym Elblągiem.

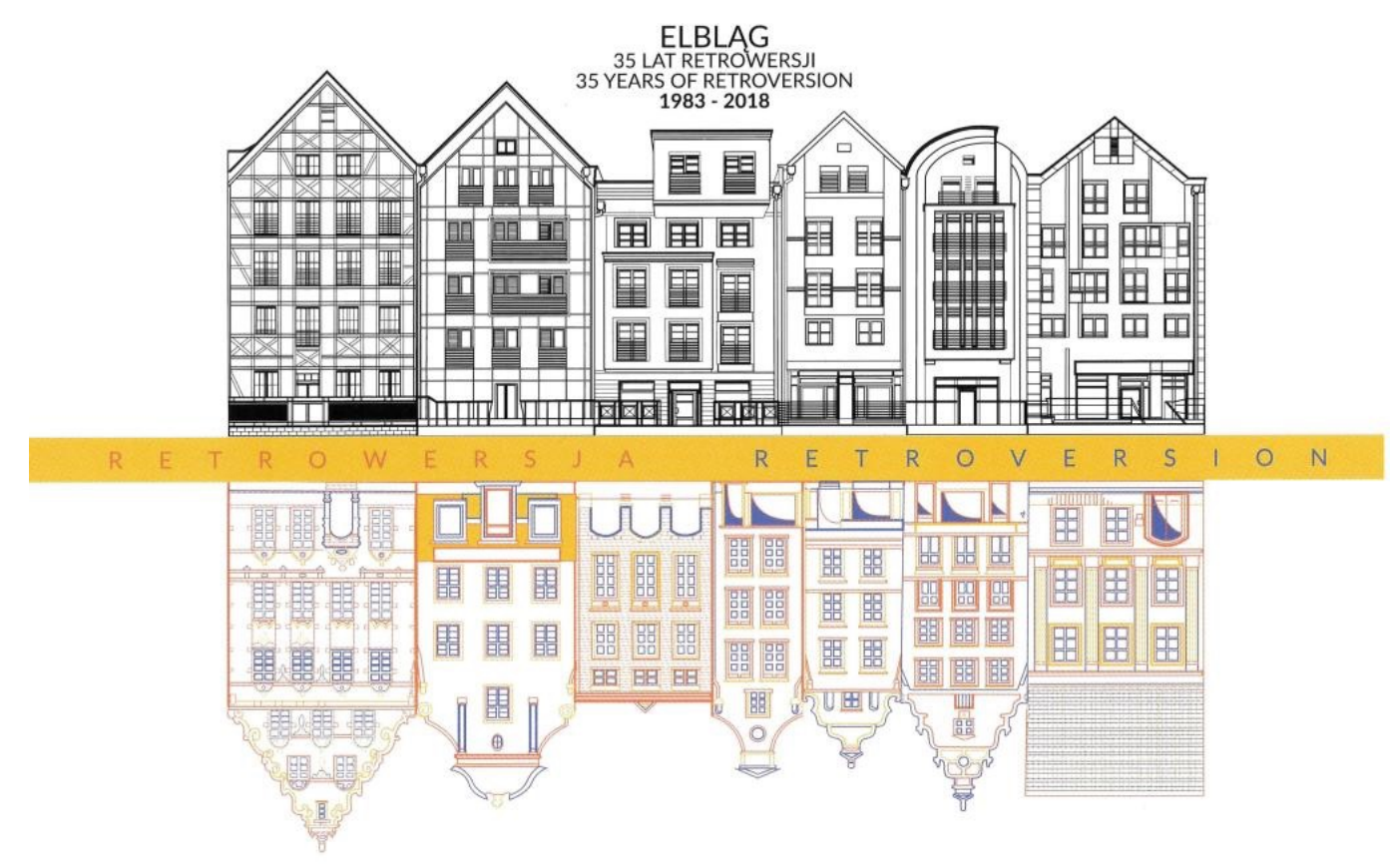

Ryc. 1 Pocztówka okolicznościowa wydana przez Urząd Miejski w Elblągu z okazji I Wieczoru z retrowersją, który odbył się 28.11.2018 roku. Opracowanie graficzne: A. Ronżewska-Kotyńska 


\section{7}

Plan Starego Miasta w Elblągu powstał w swej ostatecznej, znanej nam formie, jeśli nie około 1237 roku, kiedy rycerze krzyżaccy i lubeczanie osiedlili się na wyspie rzeki Elbląg, to najpóźniej tuż po pożarze w 1288 roku (Anders, 1975).

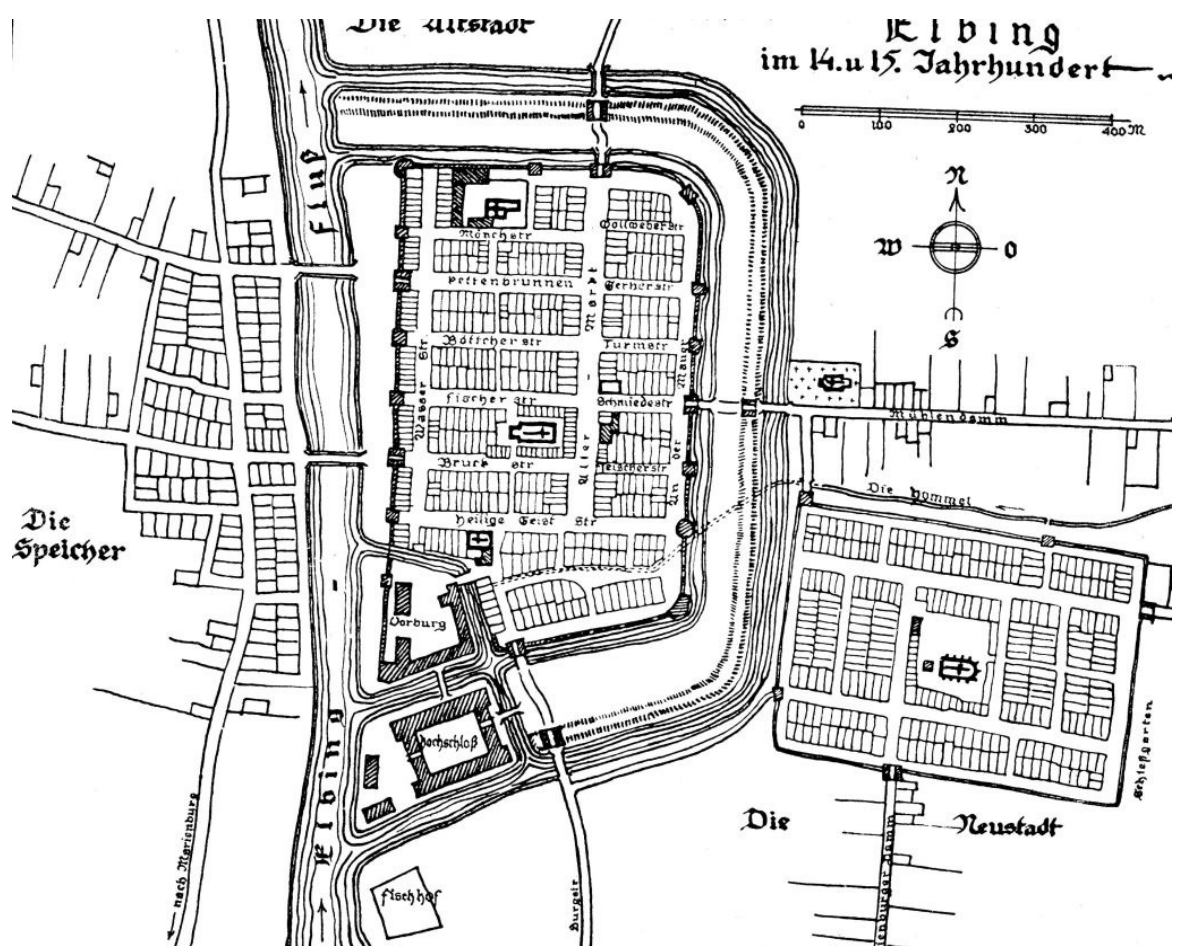

Ryc. 2 Plan miasta w XIV i XV wieku. Źródło: Registratura Departamentu Urbanistyki i Architektury UM w Elblągu

Pożar zniszczył wówczas całe miasto budowane w konstrukcji drewnianej wypełnionej gliną, z dachami pokrytymi trzciną. Jak wyglądały trzynastowieczne domy Elbląga, nie licząc zabudowy sakralnej, nie dowiemy się nigdy (Anders, 1975).

Po pożarze Elbląg z drewnianego przebudowuje się na murowany. Typ wczesnogotyckiego, już murowanego, elbląskiego domu staromiejskiego $\mathrm{z}$ wysoką, wielofunkcyjną sienią frontową, dwupoziomowym tylnym traktem mieszkalnym oraz niskimi, spichrzowymi kondygnacjami piętra zaczął kształtować sięw XIV wieku. Zasadnicze przemiany w kamienicy elbląskiej zaczynają się na przełomie XV i XVI wieku. Dotychczasowe przyziemie przemieniane jest w piwnicę i otrzymuje murowane sklepienie zamiast drewnianego stropu. Zmienione zostają poziomy użytkowania, powstają charakterystyczne przedproża. Nasilenie tego procesu przebudowy kamienic przypada na 2. poł. XVI wieku i 1. poł. XVII wieku. W wyniku tych przemian Stare Miasto o średniowiecznym planie uzyskuje charakter renesansowo-barokowy i stanowi główną wyodrębnioną przestrzennie część całego Elbląga zarówno w XVII, jak też w XIX wieku (Anders, 1996). 


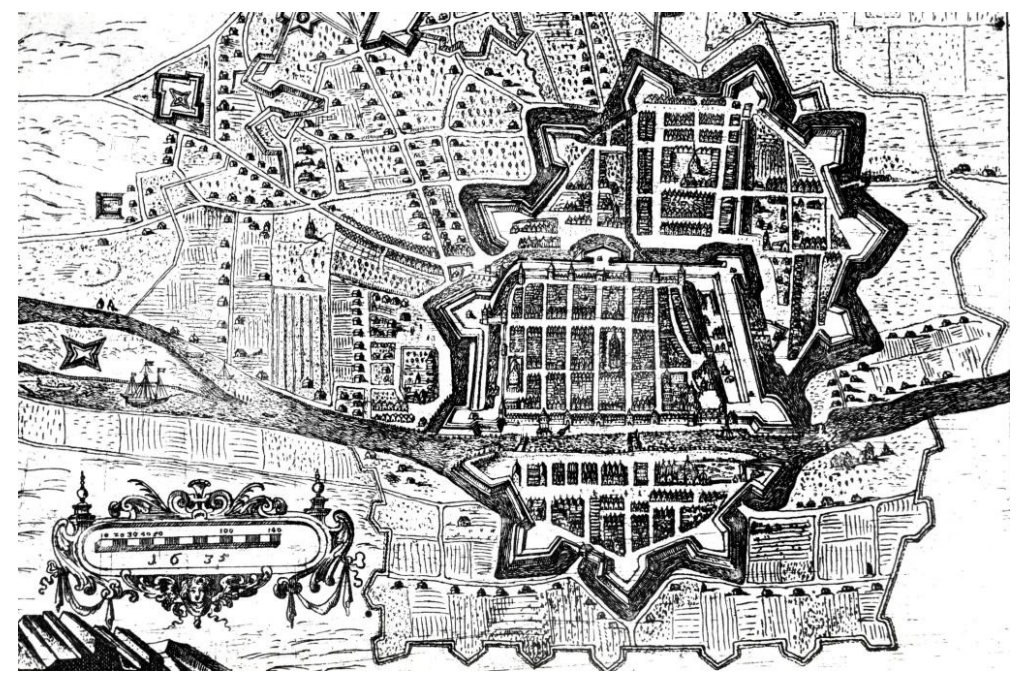

Ryc. 3 Elbląg. Plan miasta, fortyfikacji i terenów podmiejskich. Hoppe, Neumann 1635 rok. Źródło: Registratura Departamentu Urbanistyki i Architektury UM w Elblągu

Kamienice na Starym Mieście w Elblągu ulegały ciągłym przekształceniom. Do wojny polskoszwedzkiej w 1655 roku wznoszono okazałe, bogate fasady w formie architektury niderlandzkiej, częściowo przekształcone w duchu baroku. Znamienny był „Dom pod Wielbłądem” przy ul. Masztowej 30, obecnie Bednarskiej 30 (Anders, 1975). Kamienica ta powinna doczekać się rekonstrukcji fasady w najbliższej przyszłości.
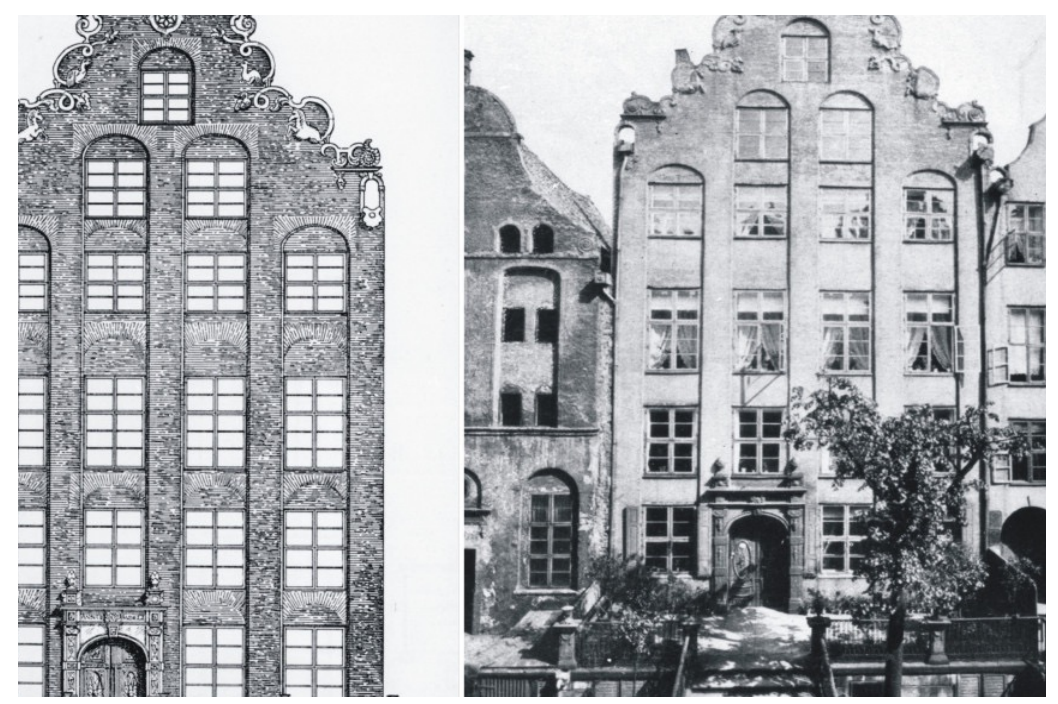

Ryc. 4 Dom pod Wielbłądem, ul. Bednarska 30.Źródło: Registratura Departamentu Urbanistyki i Architektury UM w Elblągu 
W XVIII wieku powstawały fasady już znacznie skromniejsze, z reguły tynkowane, których jedynymi dekoracjami były szczyt i stolarka drzwi wejściowych. Z czasem dekoracje szczytów ograniczono do płynnej linii rokokowego gzymsu wieńczącego (Anders, 1975).

I rozbiór Polski zapoczątkował okres opadania krzywej rozwoju przestrzennego Starego Miasta. Nieco późniejszym punktem stało się w tym okresie pojawienie się w Elblągu form klasycystycznych. Na terenie Starego Miasta najwyższej miary osiągnięciem klasycyzmu z około 1800 roku był okazały dom przy ul. Masztowej 10, późniejszy Dom Rzemiosł (Anders, 1975), obecnie niezabudowana parcela przy ul. Bednarskiej 10.
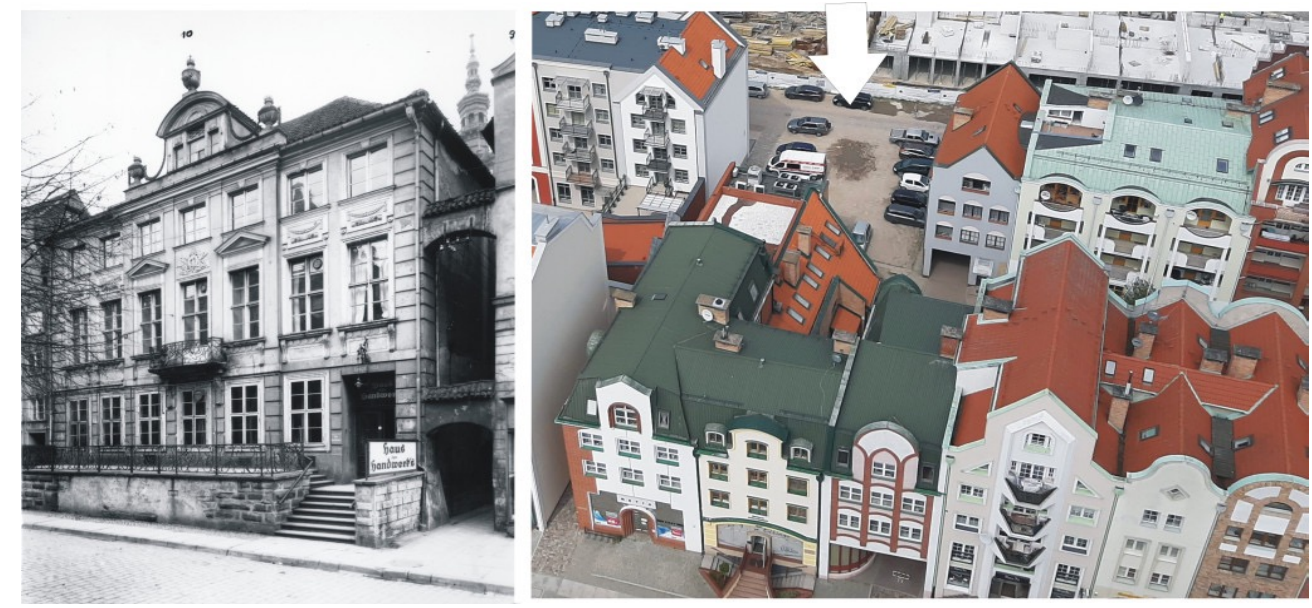

Ryc. 5 Ulica Masztowa 10, budynek w roku 1920 i niezabudowana parcela sto lat później.

Źródło: Registratura Departamentu Urbanistyki i Architektury UM w Elblągu]. Fot. K. Wiśniewska

Okres przekształceń i przebudów w formach eklektycznych, secesyjnych i modernistycznych szybko i na ogół radykalnie zacierał bądź wręcz likwidował ślady wspaniałej przeszłości architektonicznej Starego Miasta w Elblągu.

Reszty dokonała wojna w 1945 roku oraz przeprowadzone w latach 60. totalne roboty porzadkowe (Anders, 1975).

\section{5}

Straty w zabudowie Starego Miasta po wojnie szacowano na 98\%. Zachowało się jedynie 6 domów. Pierwsze prace porządkowe polegały na usunięciu gruzu z ciągów komunikacyjnych. Następnie na przełomie lat 40. i 50. zabezpieczono relikty historycznej zabudowy.

Od 1948 do 1965 roku remontowano kościół św. Mikołaja, w latach 1948-49 zabezpieczono szereg kamienic, a w 1949 roku wykonano remont Bramy Targowej, przywracając jej historyczne, średniowieczne w formie pokrycie dachu (Jonakowski, 2007). 

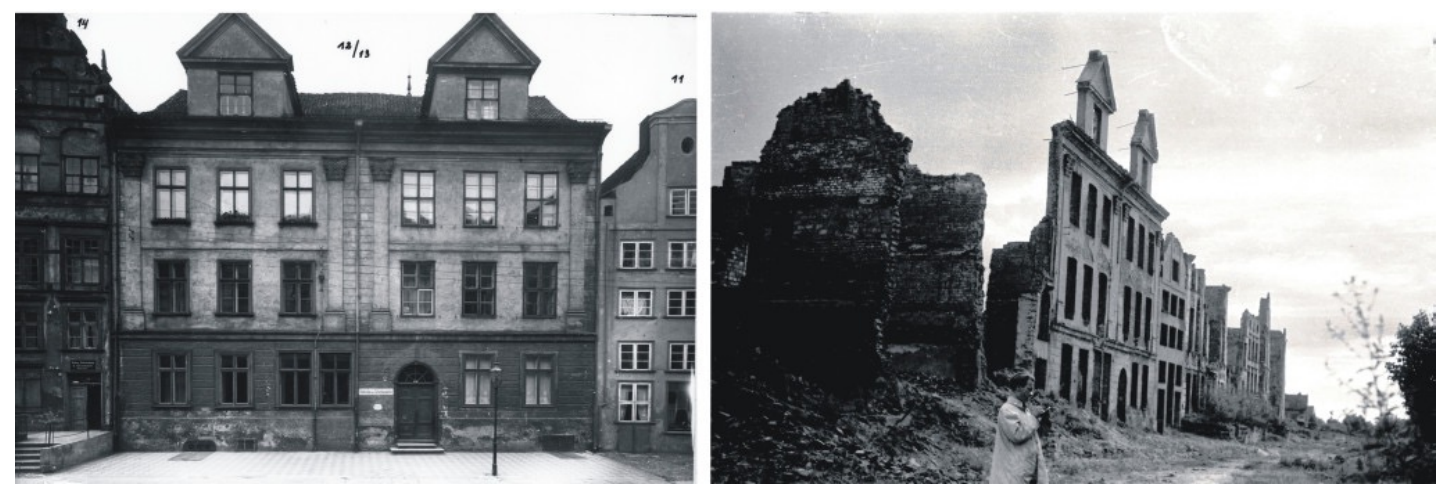

Ryc. 6 Ulica Masztowa 12/13 w roku 1920. Źródło: Registratura Departamentu Urbanistyki i Architektury UM w Elblągu]. Ten sam adres po 1945 roku. Źródło: zasoby własne

W latach 1954-55 przeprowadzono akcję inwentaryzacyjną przez studentów Wydziału Architektury Politechniki Gdańskiej, w wyniku której sporządzono 62 przekroje kamienic i 306 rzutów parterów kamienic (Lubocka-Hoffmann, 1998) - było co odbudowywać.

\section{5}

W 1955 roku Stare Miasto zaczęto oczyszczać z gruzów i pozostawiono je na uboczu odradzającego się po II wojnie światowej w innych rejonach Elbląga, rozbierając również ruiny kamienic wskazanych przez władze miasta oraz władze konserwatorskie do odbudowy. Działo się to na mocy uchwały z tego samego roku Nr 666 Prezydium Rządu w sprawie planowanej akcji usunięcia pozostałości zniszczeń wojennych w miastach i osiedlach. Celem uchwały było zainicjowanie ostatecznego usunięcia istniejących jeszcze śladów zniszczeń wojennych w miastach i osiedlach, zlikwidowania ruin i obszarów zagruzowanych (Lubocka-Hoffmann, 1998).

Jedyną drogą odbudowy, jak uważano po 1956 roku, było stworzenie zupełnie innej od poprzednich, polskiej koncepcji Elbląga. Uważano, że trzeba od początku założyć miasto na „nowym korzeniu”, bez powrotu do przeszłości (Wiśniewska, 2018). 


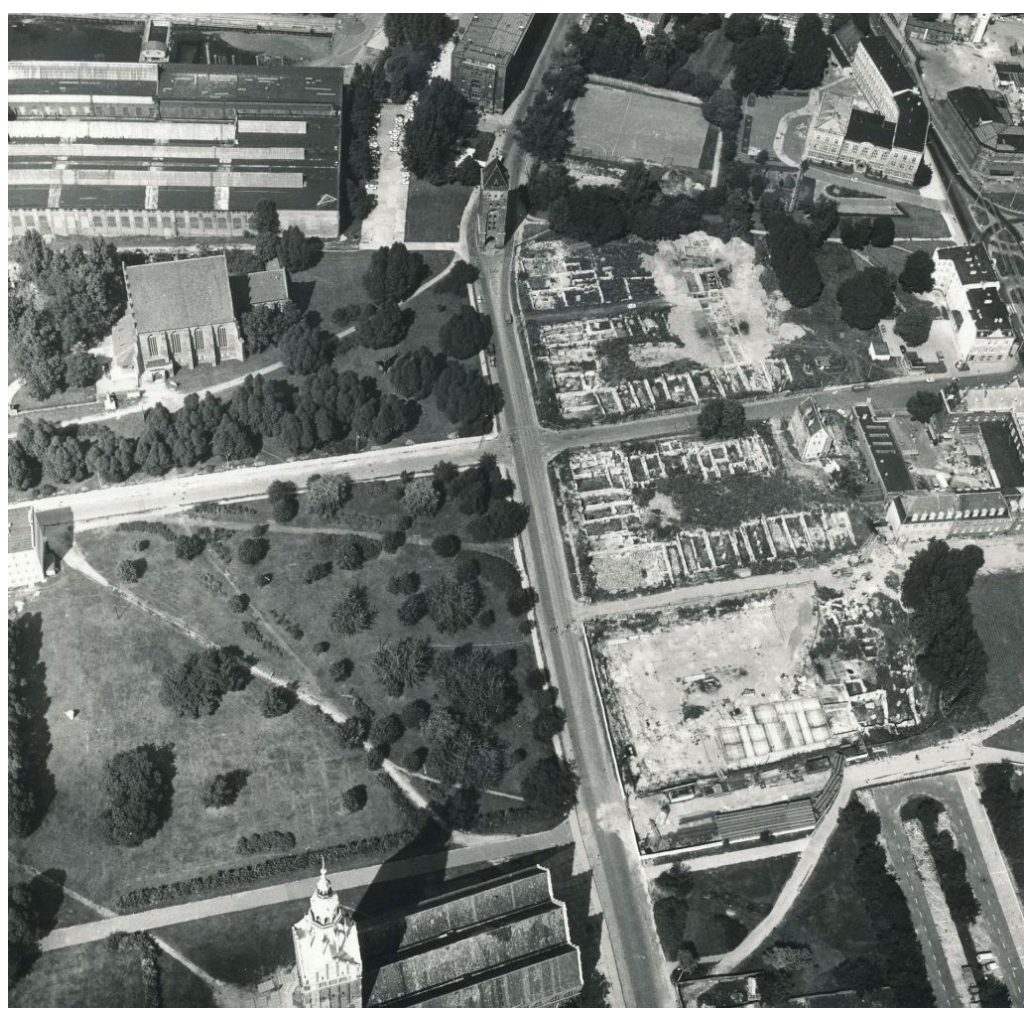

Ryc. 7 Widok na teren badań archeologicznych 1986 roku.

Źródło: Lubocka-Hoffmann, 1998

\section{8}

W 1958 powstał modernistyczny projekt zabudowy dla Starego Miasta w Elblągu zespołu w składzie: Jerzy Piaseczny, Szczepan Baum, Wiesław Anders w Zakładzie Urbanistyki Politechniki Gdańskiej kierowanym przez prof. Władysława Czernego.

Fascynujące dla młodych projektantów było to, że można robić projekt odtwarzający wczesnośredniowieczne rozplanowanie miasta z XIII wieku, które istniało przez tyle stuleci, zostało zniszczone, rozebrano gruzy, zasiano trawę. Nie było wtedy jeszcze założenia, aby budować na starych fundamentach, ponieważ nie posiadano rozpoznania archeologicznego, które miało miejsce dopiero w latach 80., a młodzi projektanci dysponowali jedynie planem miasta odrysowanym przez Włodzimierza Sierzputowskiego, konserwatora elbląskich zabytków ${ }^{1}$.

${ }^{1}$ Rozmowa z prof. Andersem z 4 marca 2020 roku, w której udział wzięli: Katarzyna Wiśniewska, Adriana RonżewskaKotyńska, Władysław Gliniecki. 


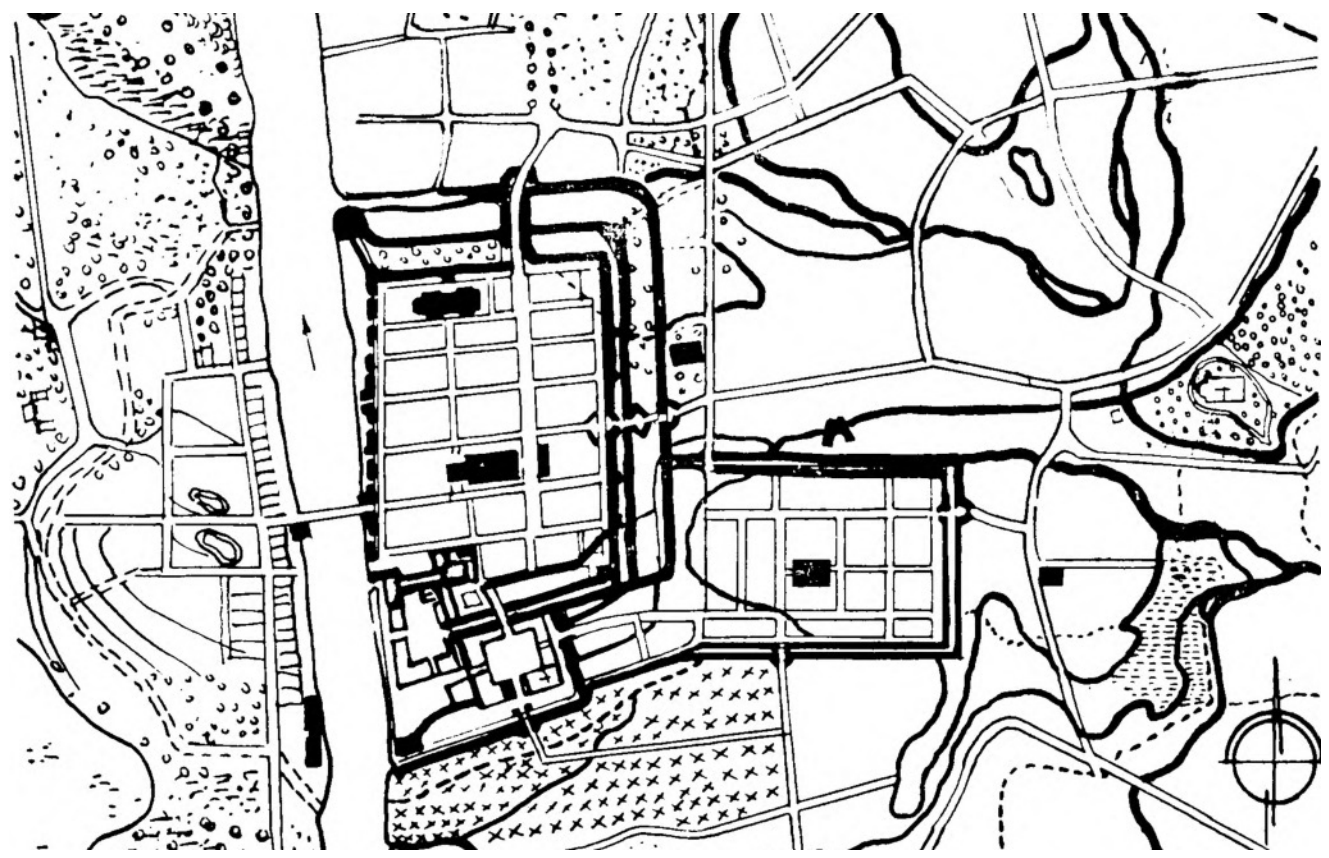

Ryc. 8 Elbląg - plan Starego i Nowego Miasta z XIV wieku. W. Sierzputowski, 1955 rok. Źródło: http:// cejsh.icm.edu.pl/

Fundamenty były zasypane ziemią, a myślą przewodnią projektu było odtworzenie rozplanowania Starego Miasta. Architektura, forma budynków również nawiązywać miała do dawnych rytmów uliczek, jednak trudność polegała na ich posadowieniu bez odkopanych fundamentów².

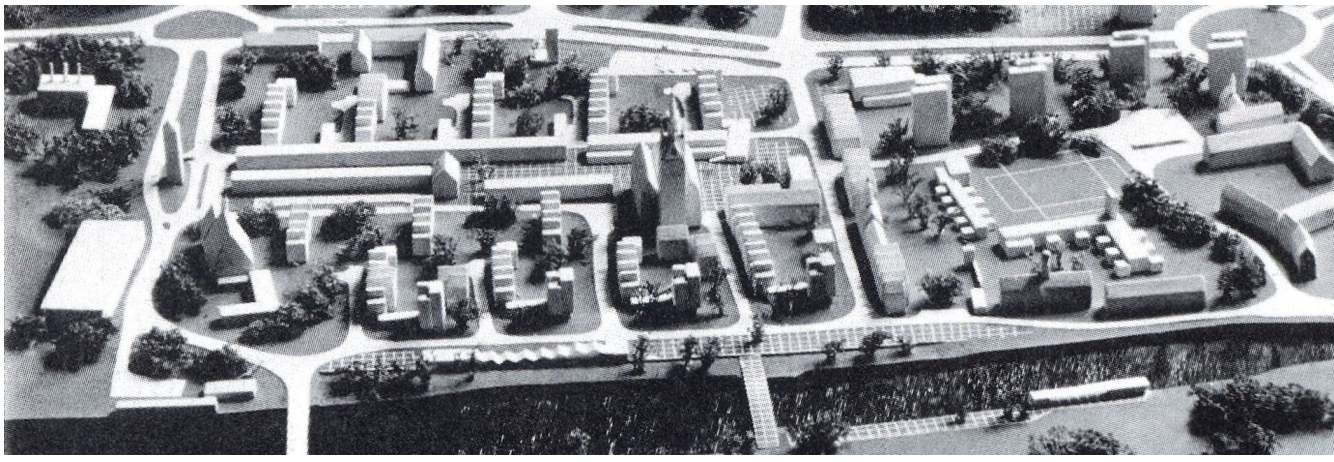

Ryc. 9 Makieta szkicu koncepcyjnego planu szczegółowego Starego Miasta w Elblągu. Autorzy: W. Anders, S. Baum, J. Pasieczny - pod kierownictwem W. Czernego, 1958 rok. Reprodukcja K. Krzępek, 1996 rok. Źródło: Lubocka-Hoffmann, 1998 
Jeden $\mathrm{z}$ autorów koncepcji, Szczepan Baum, zagorzały modernista, przekonywał w kontekście odbudowy malborskiej, że międzyścisłą rekonstrukcją historyczna a współczesnym kształtowaniem przestrzeni nie może być kompromisu lub faz pośrednich (Bugalski, 2014), co odzwierciedla projekt z 1958 roku. Koncepcja ta przetrwała do lat 70., które przyniosły rozwój budownictwa mieszkaniowego na obrzeżach śródmieścia. W kształtującym się nowym mieście zaczęto dostrzegać brak centrum i wiązać ten problem z dużym niezabudowanym terenem Starego Miasta w centralnej części Elbląga.

Podobna realizacja w Malborku doczekała się wyraźnej krytyki, ponieważ z punktu widzenia konserwatorskiego zasadniczym minusem jest brak związku między architektura nowa i dawna $i$ że jest to po prostu nowoczesne osiedle, niemajace nic wspólnego ze Starym Miastem, a jedynie dobrze komponujące się z nielicznymi reliktami przeszłości (Bugalski, 2014).

\section{9}

Decyzją konserwatorską z 1959 roku uznano za zabytek układ urbanistyczny Starego Miasta wraz ze znajdującymi się na tym obszarze historycznymi budowlami, murami i fasadami zburzonych domów.
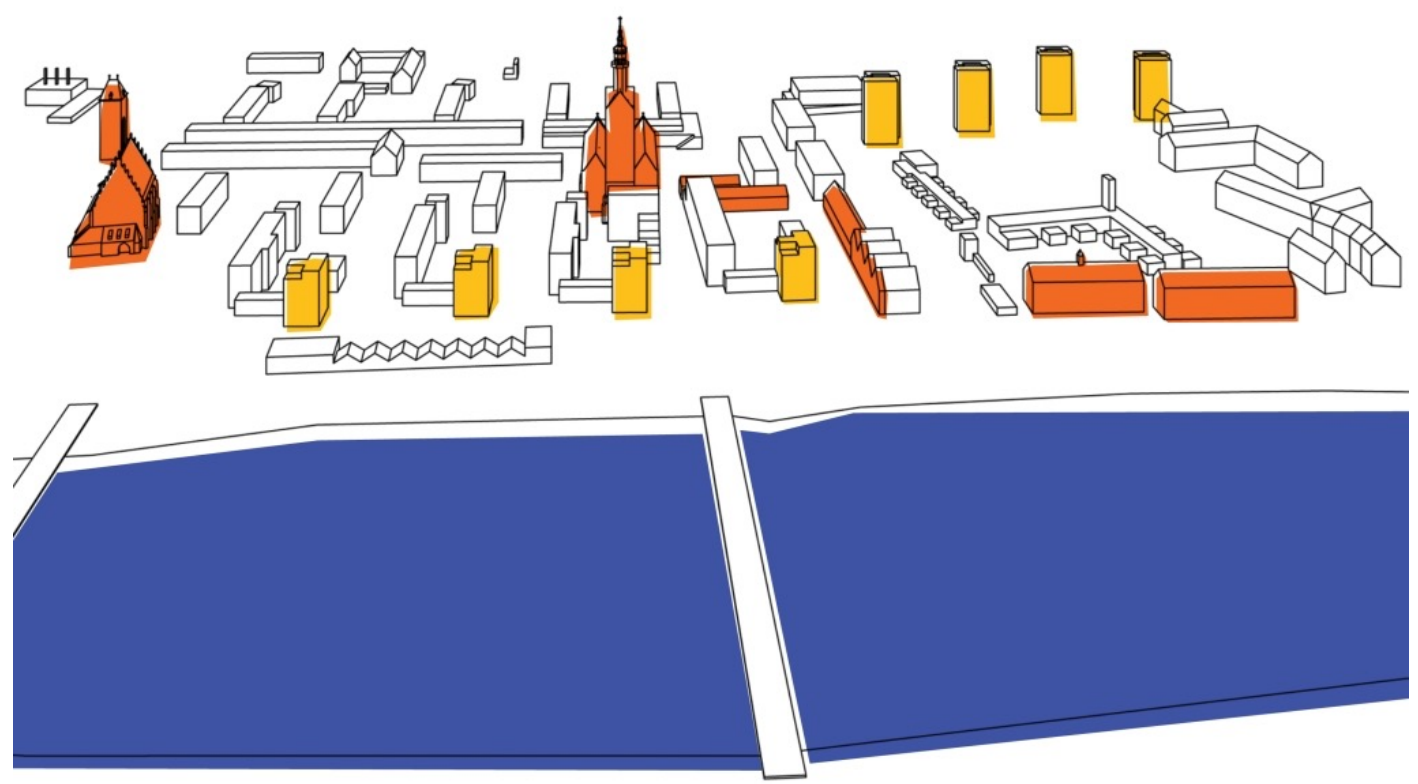

Ryc. 10 Fragment planu odbudowy Starego Miasta z 1958 roku. Opracowanie graficzne: A. Ronżewska-Kotyńska

W tym miejscu warto wspomnieć, że dzięki prowadzonym od lat 80. XX wieku szerokim badaniom archeologicznym mury odkryte spod ziemi objęte były badaniami architektonicznymi. Wnioski pobadawcze służyły do sformułowania wytycznych konserwatorskich. 


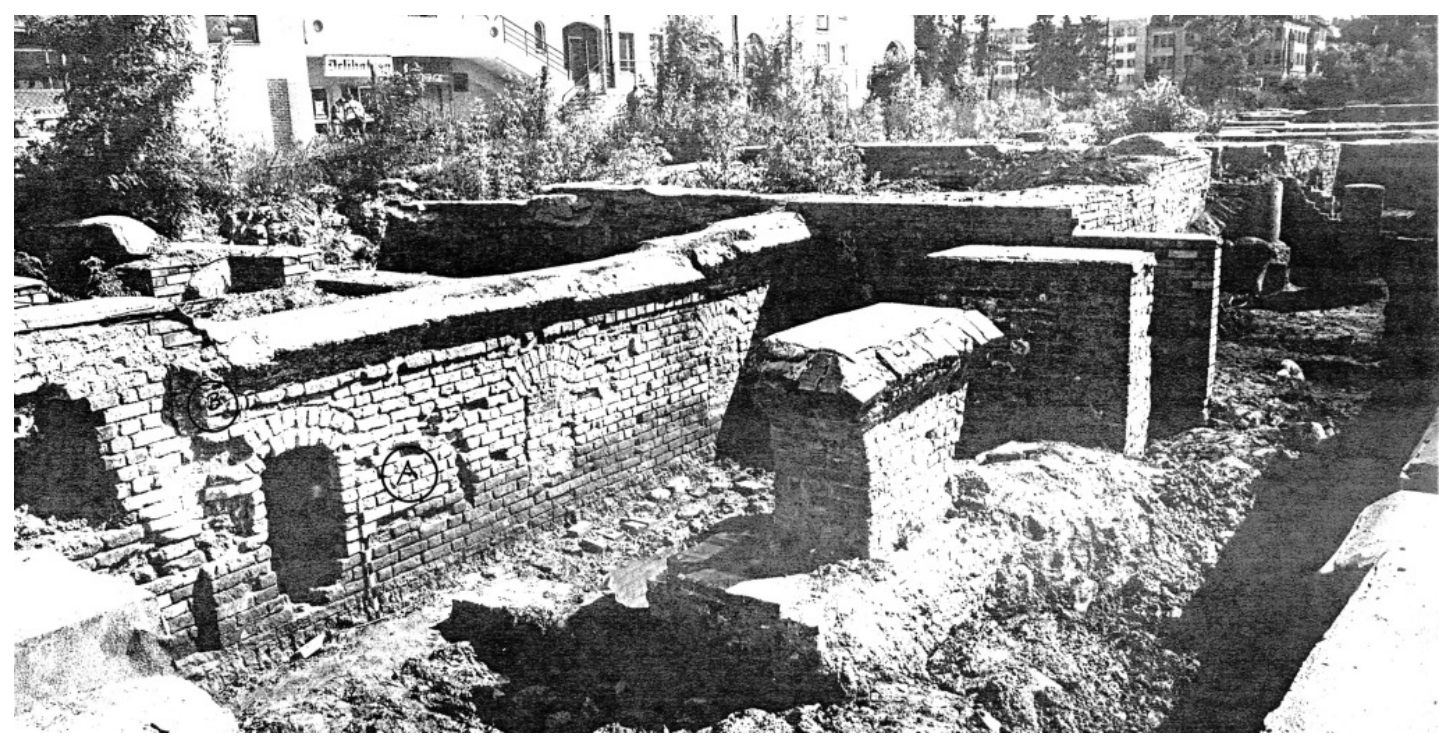

Ryc. 11 Mury dawnego Ratusza Staromiejskiego przy ul. Stary Rynek. Źródło: Registratura Departamentu Urbanistyki i Architektury UM w Elblągu

W przypadku dawnego Ratusza Staromiejskiego wytyczne konserwatorskie stanowiły, że mury nowego ratusza należy stawiać na starych odsłoniętych murach. Zakres adaptacji murów miał określić konstruktor. Warto podkreślić również nakaz wyeliminowania stylu historyzującego i projektowanie w tzw. klimacie. Podobne wytyczne dotyczyły wszystkich realizacji do 2002 roku.

Na historycznych murach stanął współczesny Ratusz Staromiejski, niestety bez wyeksponowanych w piwnicy murów gotyckich.

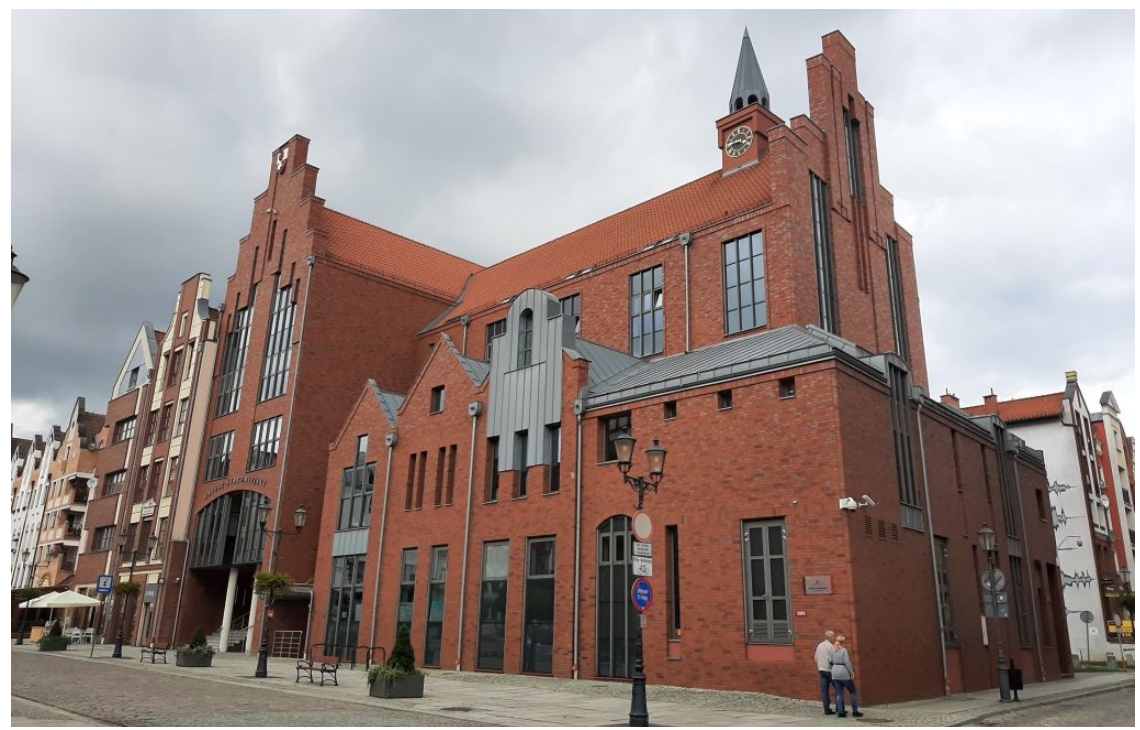

Ryc. 12 Ratusz Staromiejski - autor projektu architektonicznego z 2005 roku: W. Grodzka. Fot. K. Wiśniewska, 2021 


\section{4}

Spór pomiędzy władzami Elbląga a środowiskiem konserwatorskim wspieranym przez proboszcza parafii św. Mikołaja w latach 70. XX wieku o kształt centrum miasta i o budowę 11-piętrowego wieżowca oraz pawilonu handlowego, jako domen nowoczesnego centrum, dał początek pracom nad rewaloryzacją miasta zgodną z duchem dawnej i współczesnej wartości staromiejskiej dzielnicy Elbląga (Wiśniewska, 2018). W roku 1974 powstała inicjatywa środowiska ludzi, którzy byli zaznajomieni z przedmiotem Starego Miasta w Elblągu i czuli potrzebę odtworzenia śladów miejskiego osadnictwa wczesnośredniowiecznego.

W latach 1974-1976 powstawał dokument Studium programu i wytycznych do przestrzennego ukształtowania zabudowy Starego Miasta jako elementu śródmieścia Elblaga pod kierownictwem Wiesława Andersa, przy udziale architektów Bauma i Semki ${ }^{3}$ Założenia Studium brzmiały następująco:

1. odtworzenie historycznego planu urbanistycznego Starego Miasta przez utrzymanie dawnych linii zabudowy i głównych podziałów przestrzennych,

2. utrzymanie charakteru zabudowy przez ograniczenie jej wysokości, zachowanie rytmu w elewacjach ciągów zabudowy,

3. rekonstrukcja części kamieniczek o wysokich walorach estetycznych i kulturowych posiadających przekazy historyczne i materiał ikonograficzny,

4. uwidocznienie w terenie zabytkowych linii przedproży,

5. prowadzenie badań archeologicznych we wskazanych planem miejscach.

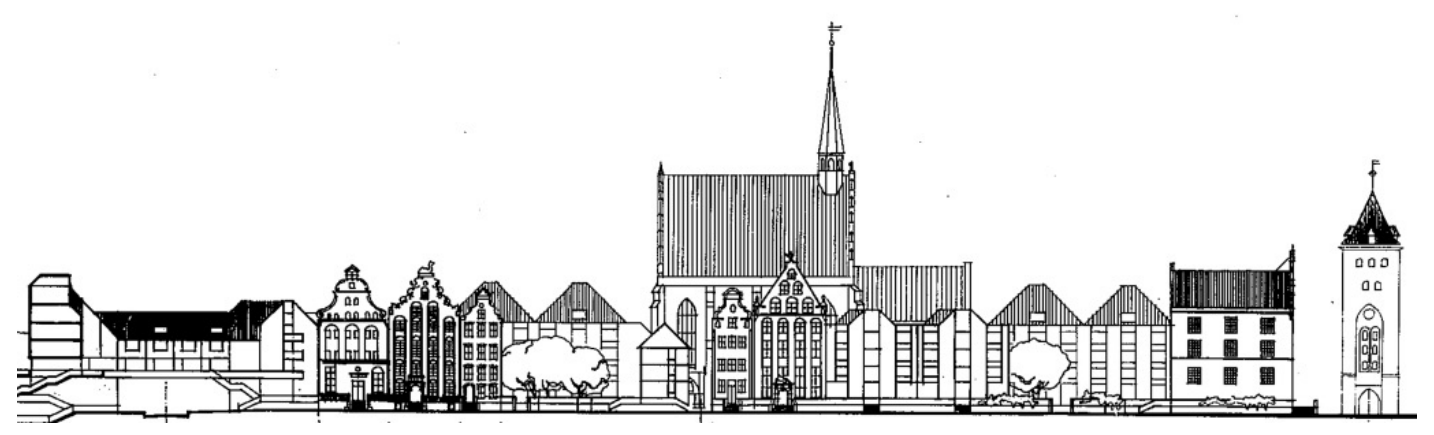

Ryc. 13 Fragment projektu zabudowy Starego Miasta, ulica Bednarska, W. Anders, S. Baum, R. Semka, 1978. Źródło: Registratura Departamentu Urbanistyki i Architektury UM w Elblągu

3 Studium opracowali następujący uczestnicy Seminarium: Przewodniczący Seminarium: W. Anders; Zespół ds. koncepcji ogólnej zagospodarowania przestrzennego: W. Anders - kierownik zespołów, S. Baum, L. Dziurdziński, R. Semka; Zagadnienia założeń programowych: T. Woronowicz; Zespół ds. historii architektury i ochrony zabytków: J. Ciemnołoński, T. Piaskowski, J. Stankiewicz, M. Zeidler; Zespół reprezentujący władze miejskie Elbląga w zakresie gospodarki przestrzennej i urbanistyki: A. Barszczyńska, J. Bocheński, J. Niedziółko; Zagadnienia komunikacji miejskiej: J. Góra; Zagadnienia miejskich systemów inżynieryjnych: J. Adamus; Sekretarz Organizacyjny Seminarium: M. Czernichowska. 


\section{Katarzyna Wiśniewska}

Ponadto w Studium określono pole możliwych rozwiązań projektów realizacyjnych, dobrych dla ukazania historii i rozwoju tego zespołu miejskiego: minimum 30 kamienic do odtworzenia, maksimum 70. Planowane rekonstrukcje miały dotyczyć fasad ważniejszych kamienic.

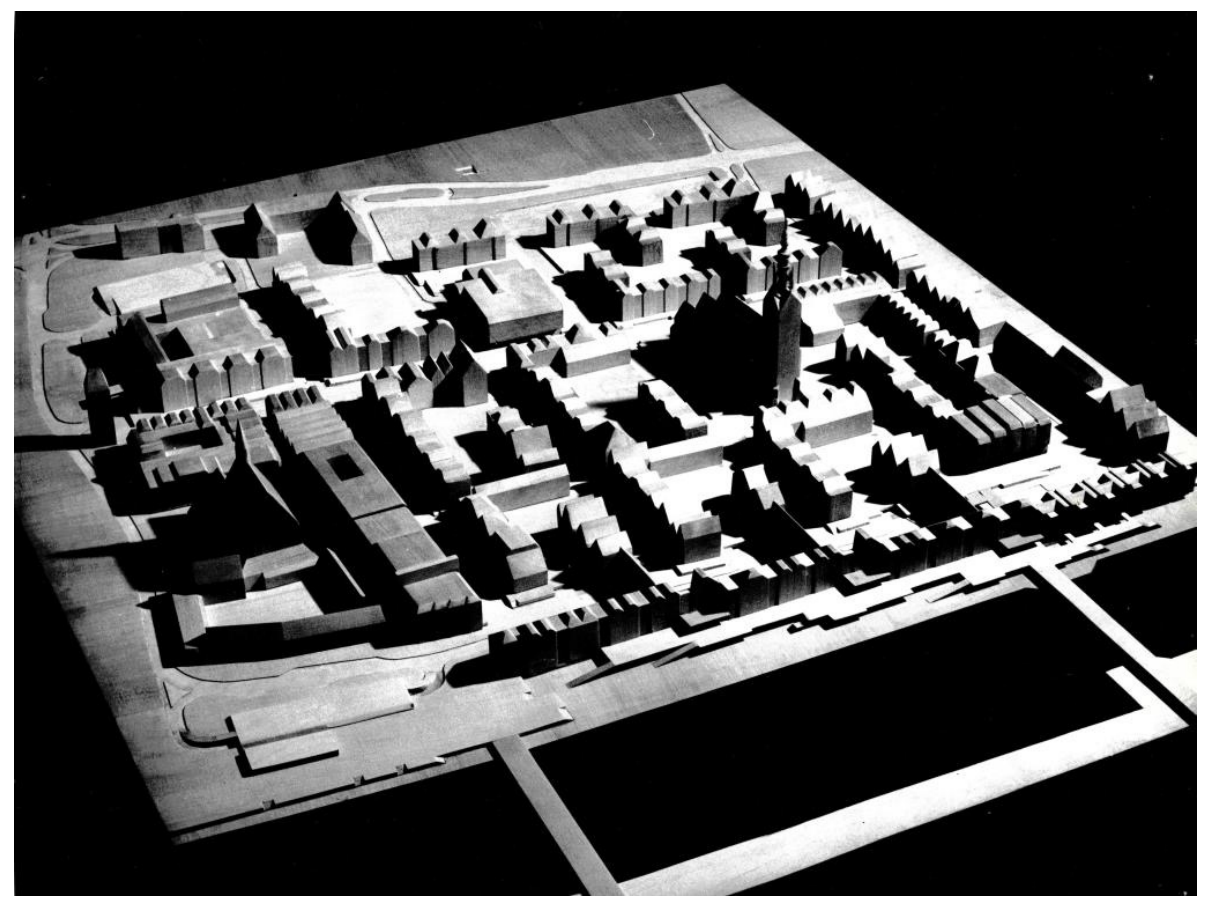

Ryc. 14 Model zabudowy Starego Miasta z Projektu zabudowy Starego Miasta w Elblągu. W. Anders, S. Baum, R. Semka, Gdańsk 1976-78. Źródło: Registratura Departamentu Urbanistyki i Architektury UM w Elblągu

\section{8}

Projekt zabudowy Starego Miasta w Elblaguz 1978 roku autorstwa W. Andersa, S. Bauma i R. Semki zakładał realizację na historycznej siatce ulic pięciokondygnacyjnych bloków mieszkalnych, tworzących pierzeje uliczne. Pomimo tego, że projekt został uznany przez władze miejskie w 1978 roku uchwałą Rady Miasta Elbląga za Miejscowy plan szczegółowy zagospodarowania przestrzennego zespołu staromiejskiego Elblaga (Anders, 1996), odbudowy tej nie podjęto, a zastrzeżenia do projektu w 1979 roku, wskazujące na różnice między założeniami Studium a wytycznymi konserwatorskimi (dopiero później nazwanymi retrowersją) wniósł wojewódzki konserwator zabytków. Dotyczyły one kwestii prawdy przestrzeni staromiejskiej, relacji między starą i nową architekturą oraz lokalizacji zbyt wielu miejsc parkingowych na Starym Mieście. 


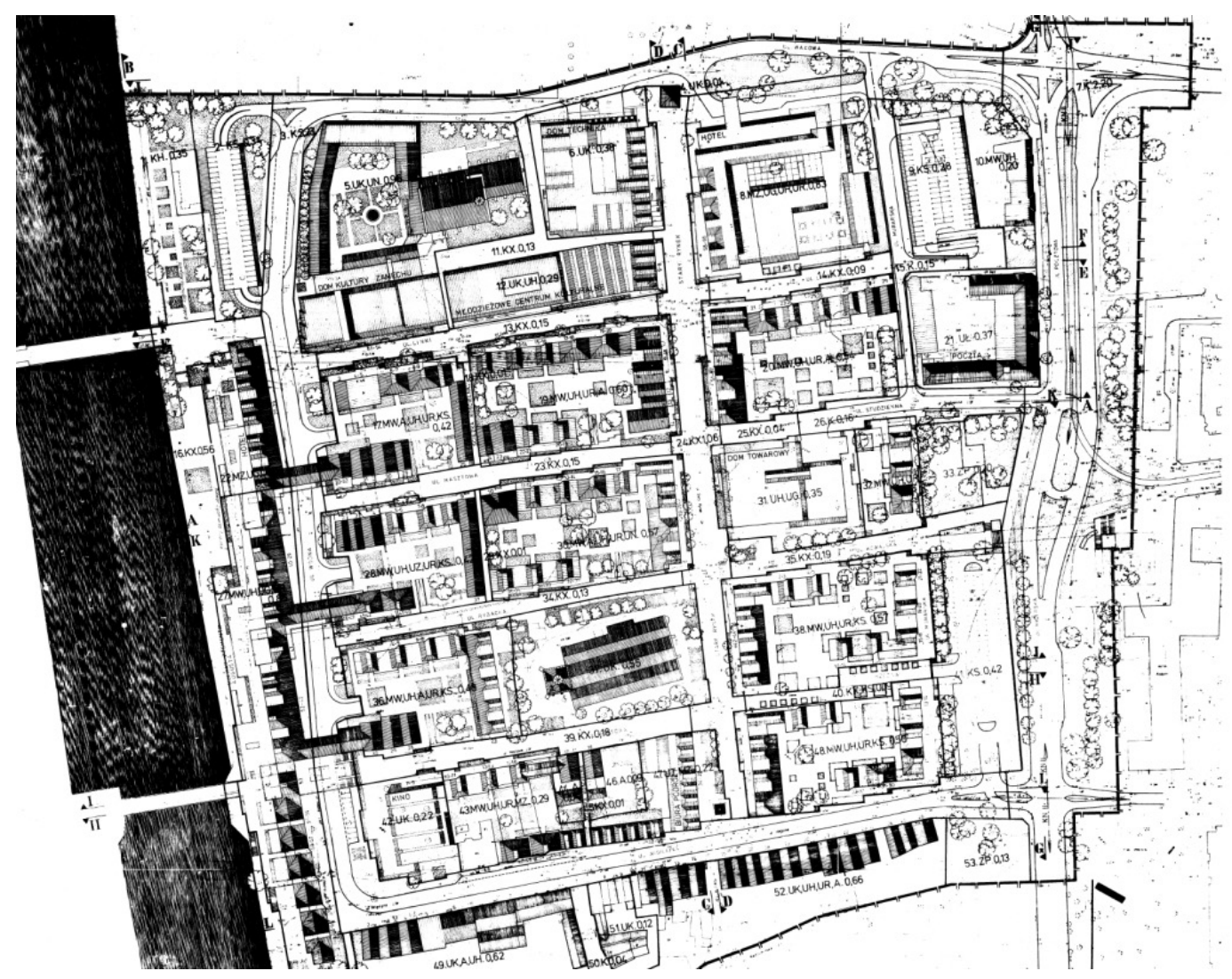

Ryc. 15 Fragment Miejscowego planu szczegółowego zagospodarowania przestrzennego zespołu staromiejskiego Elbląga 1978. Źródło: Registratura Departamentu Urbanistyki i Architektury UM w Elblągu

\section{0}

W 1980 roku, według autorki retrowersji, w Elblągu następuje powrót do dawnego wizerunku miasta. Nie jest to powrót wierny jak rekonstrukcja, ale bardziej twórczy, jak prawdziwa sztuka. Jest to powrót do ducha, a nie litery pierwowzoru. Retrowersja, poprzez właściwie zaprojektowane gabaryty, odtwarza historyczną skalę i sylwetę miasta, co miało w efekcie ukształtować na nowo krajobraz utraconego miasta i wykreować wartości utożsamiane $\mathrm{z}$ wizerunkiem i atmosferą zespołów staromiejskich (Lubocka-Hoffmann, 1998).

Zasady retrowersji to: 1) ochrona planu miasta z układem ulic na bazie reliktów murów, 2) skala zabudowy jak przed 1945 rokiem w celu odtworzenia dawnej panoramy, 3) projektowanie domów we współczesnych formach, 4) przywrócenie Staremu Miastu roli centrum.

W 1981 roku na zlecenie Wojewódzkiego Konserwatora Zabytków powstaje opracowanie Ikonografia Starego Miasta w Elblagu, wskazujące propozycję w postaci listy kamienic do rekonstrukcji. Opracowanie nie stanowiło wówczas prawa miejscowego zawierającego nakaz rekonstrukcji, nadal jest narzędziem pracy i wskazówką dla kolejnych konserwatorów zabytków w podejmowaniu decyzji o rekonstrukcjach kamienic, czy ich fasad. 


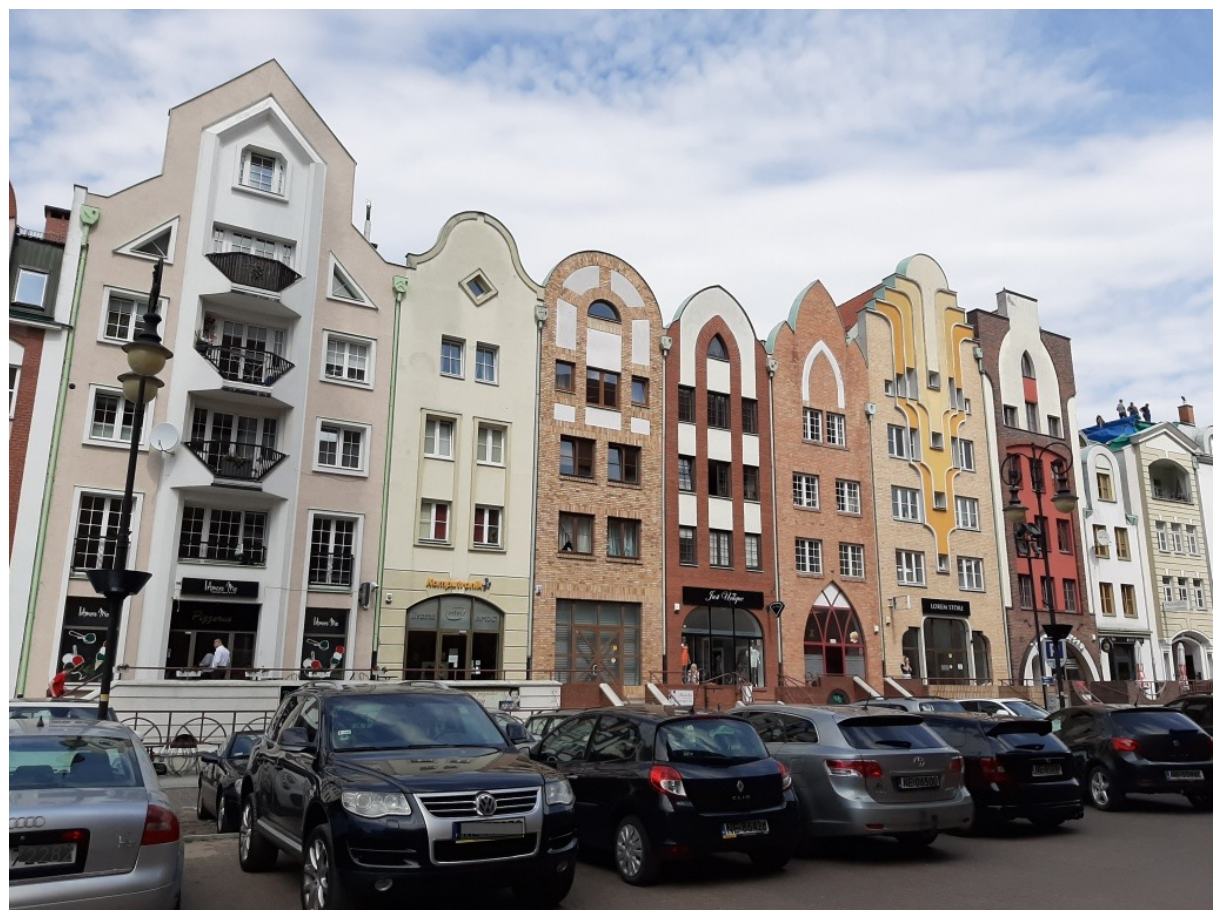

Ryc. 16 Ulica Rybacka w Elblągu - realizacja metodą retrowersji, autorzy projektu architektonicznego z 1996 roku: S. Baum, R. Semka. Fot. K. Wiśniewska

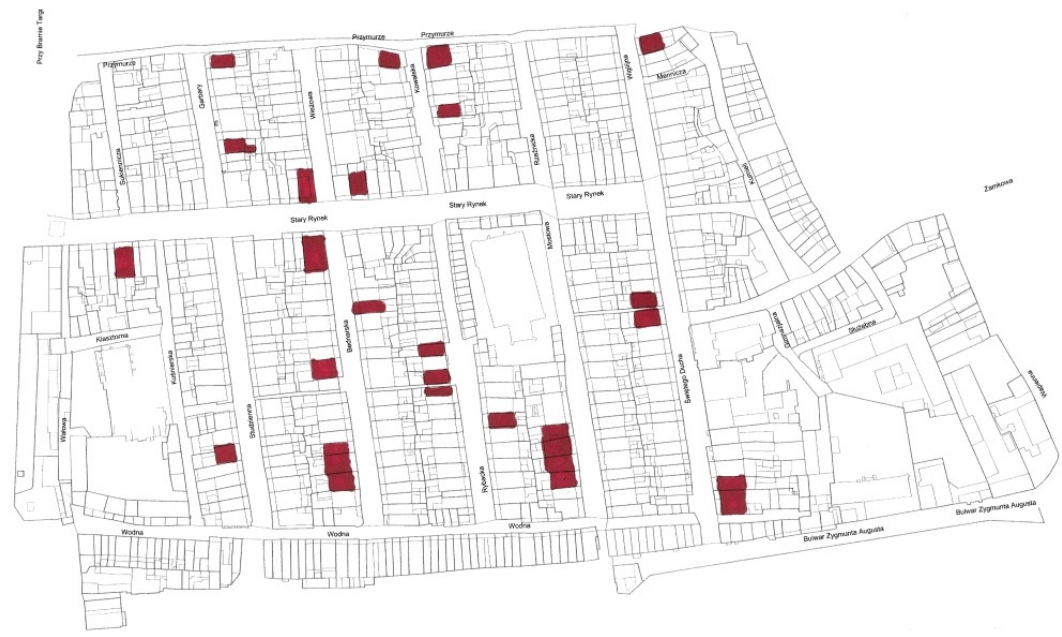

Ryc. 17 Proponowane kamienice do rekonstrukcji według Ikonografii Starego Miasta w Elblągu z 1981. Opracowanie: K. Wiśniewska 
Chociaż na liście tej nie znalazły się najpiękniejsze w uznaniu mieszkańców kamienice, z prawdą mija się twierdzenie, że retrowersja zdecydowanie przeciwstawia się rekonstrukcjom (Bugalski, 2014). Zdecydowano się na odtworzenie kilkunastu fasad kamienic, aby ukazać bogactwo detali i zamożność elblążan, ponieważ domy w Elblągu dorównywały kamienicom Starego Miasta w Gdańsku.
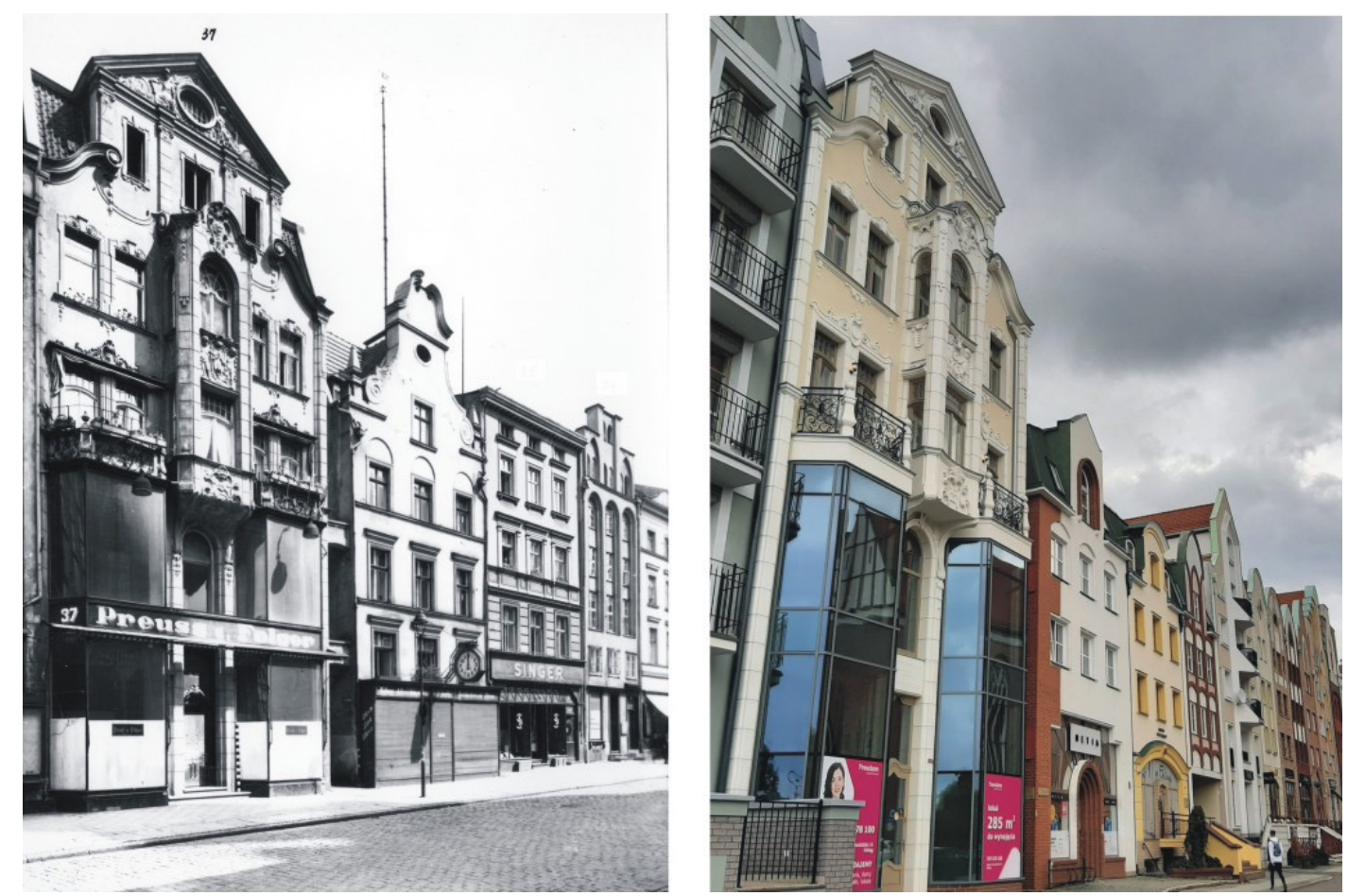

Ryc. 18 Ulica Rybacka 37 w Elblągu, rok 1920 i 2021; autor projektu architektonicznego z 2018 roku: W. Sobczak. Źródło: Registratura Departamentu Urbanistyki i Architektury UM w Elblągu. Fot. K. Wiśniewska, 2021

\section{7}

Obowiązujący do dzisiaj miejscowy plan zagospodarowania przestrzennego Starego Miasta w Elblągu przyjęto w 1997 roku, w czasie kiedy od 14 lat realizowano już kamienice metodą retrowersji. Celem planu było wykreowanie własnego symbolu tożsamości mieszkańców miasta Elbląga. Dokument nie zawiera jednak ustaleń dotyczących wskazania kamienic do rekonstrukcji. Element ten pozostaje zatem decyzją uznaniową służb konserwatorskich.

Procedura uzyskiwania pozwoleń konserwatorskich i wymogu odtworzenia fasad odbywała się dotychczas bez zażaleń ze strony inwestorów, bowiem stosunek odtwarzanych kamienic do ich łącznej liczby w poszczególnej pierzei jest znikomy. Planowana zabudowa przy ulicy Bednarskiej, przy której Studium z lat 1974-76 oraz Ikonografia z roku 1981 wskazują w kwartale na wschód od ścieżki kościelnej trzy kamienice do rekonstrukcji, nie będzie eksponowała żadnej odrestaurowanej fasady - w świetle prawa. 

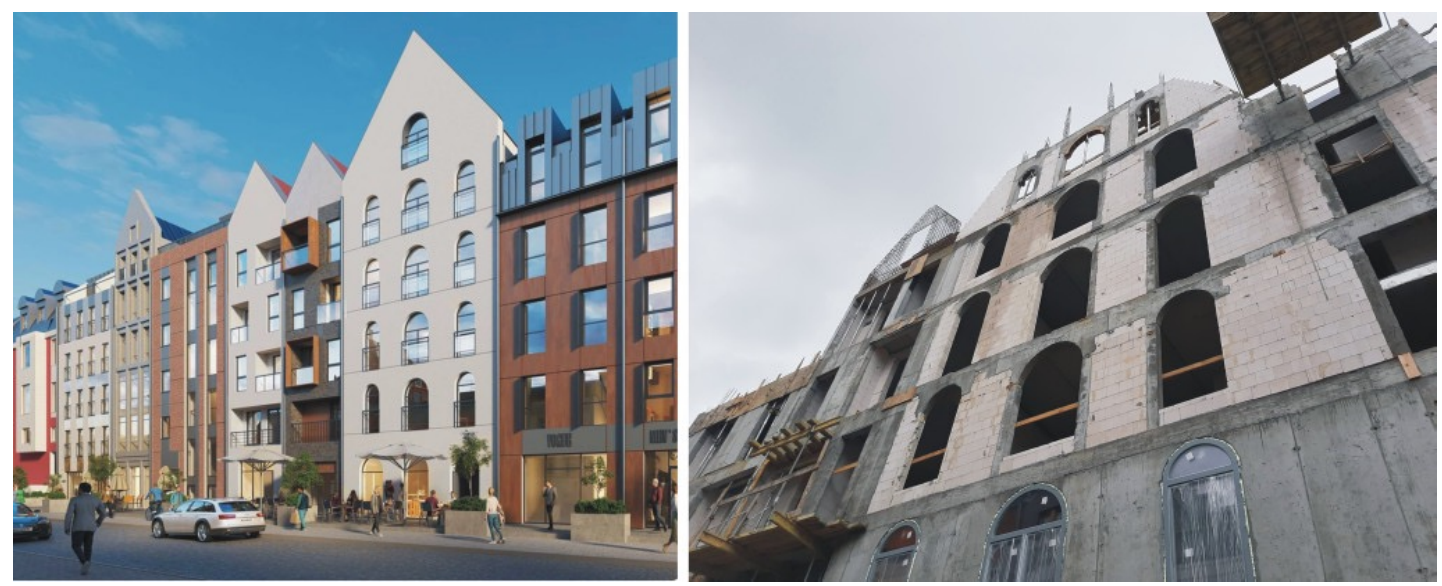

Ryc. 19 Wizualizacja południowej pierzei ul. Studziennej, 2021; autor projektu architektonicznego z roku 2020: P. Pałdyna. Źródło: https://bulvar-elblag.pl/. Fot. K. Wiśniewska

\section{4}

W 2004 roku wydane zostaje pozwolenie konserwatorskie i pozwolenie na budowę fragmentu pierzei przy ulicy Stary Rynek (obecnie Hotel Elbląg) z rekonstrukcją fasady oraz pierwszym parkingiem podziemnym, wbrew zamysłowi metody konserwatorskiej, jednakże opierając się na zapisach prawa miejscowego obowiązującego od 1997 roku. Nastąpiło to dwa lata po zakończeniu pełnienia funkcji Wojewódzkiego Konserwatora Zabytków przez autorkę retrowersji. Nowy konserwator zabytków został postawiony przed trudnym zadaniem pogodzenia założeń konserwatorskich z rzeczywistością inwestycyjną XXI wieku.
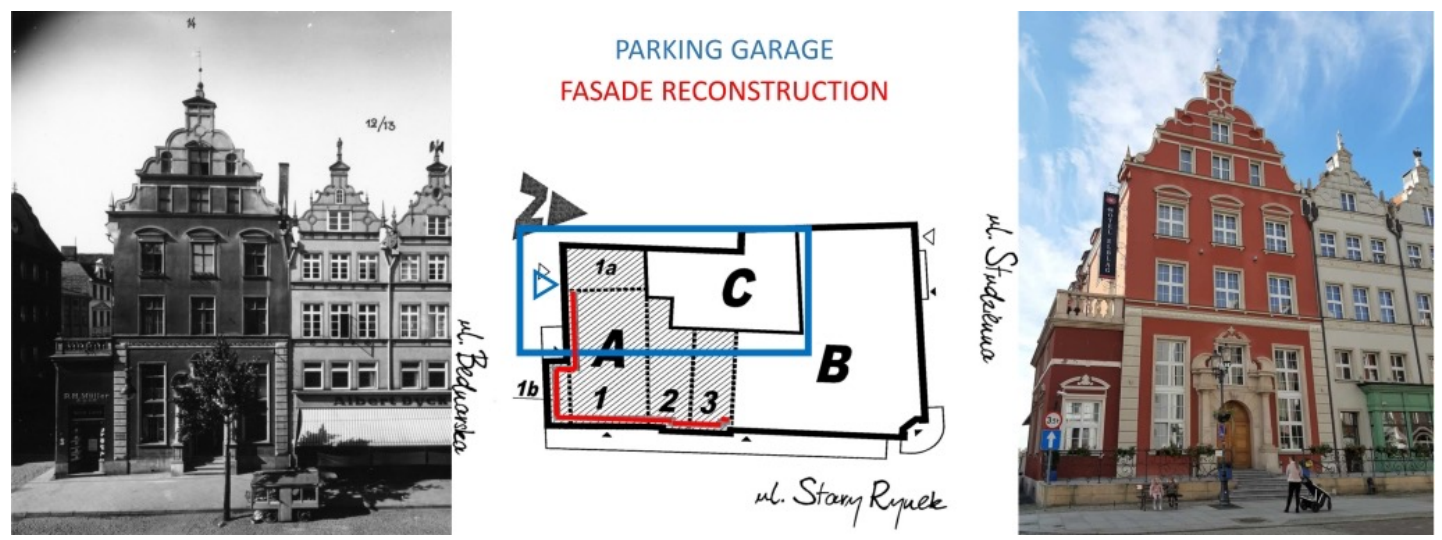

Ryc. 20 Kamienica przy ul. Stary Rynek 14 w Elblągu: 1920 rok, 2004 - szkic koncepcyjny do pozwolenia na budowę i rok 2021; autor projektu architektonicznego z roku 2004: P. Pałdyna. Źródło: Registratura Departamentu Urbanistyki i Architektury UM w Elblągu. Fot. K. Wiśniewska 
W moim przekonaniu od tego momentu zaczyna się okres liberalizacji zasad konserwatorskiej metody retrowersji, opartej na rozstrzygnięciach konserwatorskich. Podkreślenie przeze mnie uznaniowości decyzji konserwatorskich ma dowieść, że ustalenia zapisane w planie miejscowym w 1997 roku oraz założenia retrowersji sprzed dwudziestu czterech lat zawierają intencje dotyczące formy przyszłej zabudowy znane $\mathrm{w}$ istocie ich autorom, którzy będąc zarazem decydentami, odczytywali je we właściwy w tamtym czasie sposób. Dzisiaj zapisane wówczas prawo miejscowe intepretowane jest przez inwestorów, projektantów, decydentów w kontekście zupełnie innej rzeczywistości inwestycyjnej i skomplikowanego stanu prawnego.

Reasumując, założenia do projektowania z roku 1976, które zostały zanegowane przez konserwatora zabytków w roku 1979, de facto aktualnie są realizowane. Bowiem współczesne potrzeby mieszkańców, inwestorów, rynku, zmieniające się prawo, orzecznictwo sądów stopniowo dostosowywały interpretację ustaleń planu miejscowego z 1997 roku, powstałego na kanwie zasad retrowersji, do współczesności.

Współczesna kamienica z parkingiem podziemnym usytuowana po obrysie historycznych murów jest zgodna z zapisanym prawem miejscowym. Powstaje pytanie, czy nadal reprezentuje konserwatorską metodę retrowersji, czy jedynie marketingowe hasło retrowersja, które powoli przeformułowywane jest na hasło Nówka Starówka?

Obecnie kontrowersje budzi nie tyle likwidowanie pozostałości gotyckich murów fundamentowych, które nie spełniają wymogów technicznych dla posadowienia budynku (podlegają rozpoznaniu archeologicznemu), co forma nowoczesnych fasad.

Czy jednak jakość architektury powinna mieć wpływ na ważkość idei retrowersji? Współczesność każdej dekady w tym bardzo długim, stąd różnorodnym procesie retrowersji budziła kontrowersje.

Wiesław Anders w referacie wygłoszonym w Elblągu w 1994 roku mówił: Sądzę, że zapoczątkowana i nie zakończona jeszcze odbudowa pozostawia nadzieję na dalsze poszukiwania twórcze rozwiąań architektonicznych, które niekoniecznie musza być podporzadkowane dotychczasowym jej rezultatom. Życzyłbym sobie, aby dalsze rozwiazania architektoniczne wniosty odmienne i lepsze wartości funkcjonalne, konstrukcyjno-materiałowe, technologiczne, wyposażeniowe i kompozycyjne, przy zachowaniu jednak generalnej zasady widocznego odtwarzania historycznego planu miasta ${ }^{4}$. Wskazywano także w czasie konferencji na ogromny problem parkingowy i nadchodzący deficyt miejsc parkingowych, z którym miasto właśnie w XXI wieku się zmaga.

\section{0}

W roku 2010 dokonano zmiany fragmentów miejscowego planu zagospodarowania przestrzennego z 1997 roku - dopuszczając realizację parkingów podziemnych - zwolniono tym samym Wojewódzkiego Konserwatora Zabytków i organ architektoniczno-budowlany z trudnej

${ }^{4}$ Z protokołu z ogólnopolskiej konferencji na temat: Odbudowa Starego Miasta w Elblagu - przywracanie ładu przestrzennego z uwzględnieniem rodzinnej struktury zabudowy, Elbląg 14.10.1994. 
interpretacji planu miejscowego przy podejmowaniu decyzji lokalizacyjnych. Od tego czasu w kwartałach realizowane są parkingi podziemne. Przy zmianie tej nie wprowadzono jednakże nakazu rekonstrukcji fasad konkretnych kamienic.

\section{8}

W roku 2018 tzw. specustawa mieszkaniowa ${ }^{5}$ umożliwiła szybką procedurę zmiany ustaleń planu, a tym samym realizację nowych bądź dokończenie wstrzymanych inwestycji w sposób uznany za bardziej opłacalny dla inwestora. Uchwałą Rady Miejskiej w Elblągu nr XI/313/2020 z dnia 23.04.2020 roku w sprawie ustalenia lokalizacji inwestycji mieszkaniowej na obszarze Starego Miasta $^{6}$ dokonano formalnego wyeliminowania twardych zasad retrowersji zapisanych w planie miejscowym, dotyczących wysokości zabudowy nawiązującej do tej sprzed 1945. Jest to pierwszy przypadek, w którym dla kilku kamienic wyeliminowano jedną z zasad retrowersji.

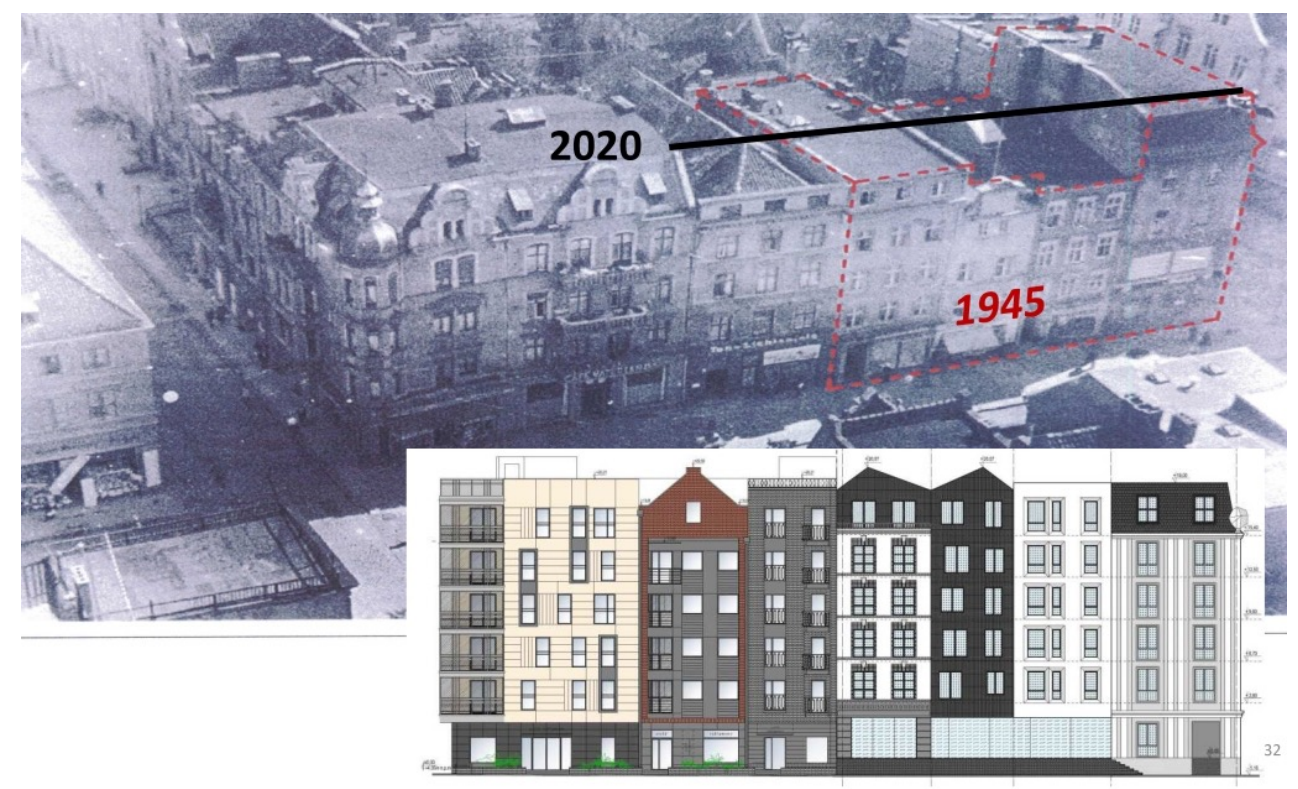

Ryc. 21 Narożnik ulic Wigilijnej i Stary Rynek. Źródło: Registratura Departamentu Urbanistyki i Architektury UM w Elblągu; http://um-elblag.samorzady.pl/art/id/53937. Opracowanie: K. Wiśniewska

\section{Retrowspółczesność}

Retrowspółczesnością nazywam realizacje współczesnych form fasad zabudowy powstałych po 2018 roku, wciąż zgodnych z zapisami planu miejscowego z roku 1997, stanowiącymi, że: Kamienice należy projektować $w$ indywidualnych wspótczesnych formach architektonicznych, eliminując styl

\footnotetext{
${ }^{5}$ Ustawa z dnia 5 lipca 2018 r. o ułatwieniach w przygotowaniu i realizacji inwestycji mieszkaniowych oraz inwestycji towarzyszących, Dz.U.2021.1538.t.j.

${ }_{6}^{6}$ Dziennik Urzędowy Województwa Warmińsko-Mazurskiego z dnia 02.06.2020 Poz. 2368.
} 
historyzujący. Dopuszcza się możliwość stosowania historycznego detalu w sposób niesugerujący, że kamienica jest obiektem zrekonstruowanym lub oryginałem z określonej epoki stylowej. Projektowana architektura musi nosić znamię czasu i miejsca, w którym powstała, a jednocześnie wykazywać się uniwersalnymi walorami estetycznymi?

\section{Teraźniejszość i przyszłość}

Co dalej? Czy potrzebne jest definiowanie nowych zasad?

$\mathrm{Na}$ decyzję właścicieli o realizacji czekają niezmiennie od kilku dekad dwie rekonstrukcje: przy ul. Garbary 13 i Bednarskiej 10.

Rezerwą pod przyszłą zabudowę jest tymczasowy plac katedralny oraz parcele nabrzeżne, gdzie stały przed wojną tzw. budy.

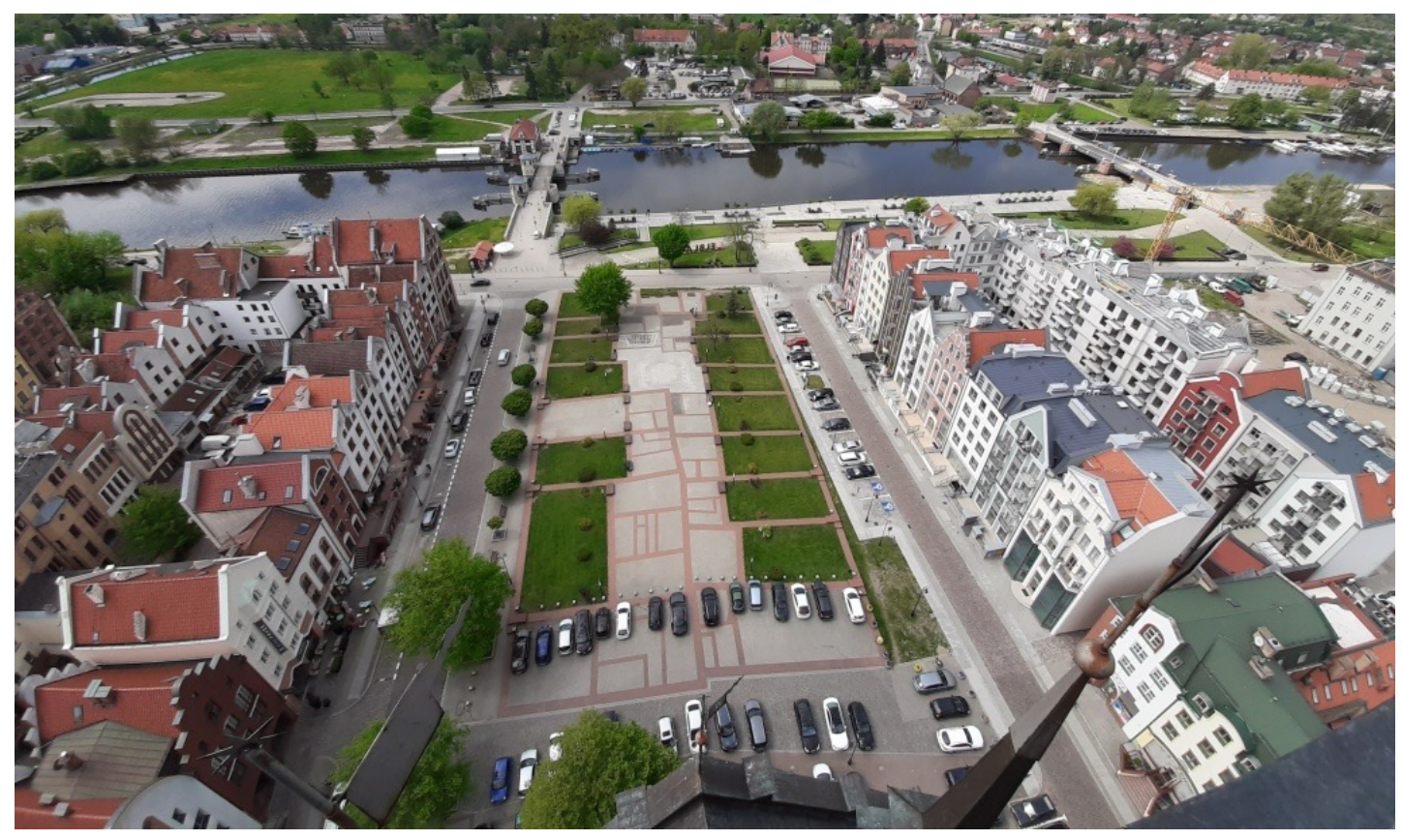

Ryc. 22 Plac Katedralny, 2021. Fot. K. Wiśniewska

Obecnie procedowana jest zmiana planu miejscowego z roku 1997 wprowadzająca nakaz rekonstrukcji dwóch fasad dawnych kamienic przy ulicy Świętego Ducha 1 i 2 . Ponadto realizowane są cztery kwartały w tzw. współczesnej, niehistoryzującej formie. Jedna z realizacji została oprotestowana przez lokalnych aktywistów, którzy tęskniąc za kreacjami na wzór tych sprzed lat, nie mają świadomości, że ich formy architektoniczne były w swoim czasie kontestowane.

${ }^{7}$ Miejscowy plan zagospodarowania przestrzennego Starego Miasta w Elblagu (uchwała Rady Miejskiej w Elblagu nr XXIX/525/97 z dnia 27.11.1997 roku). 


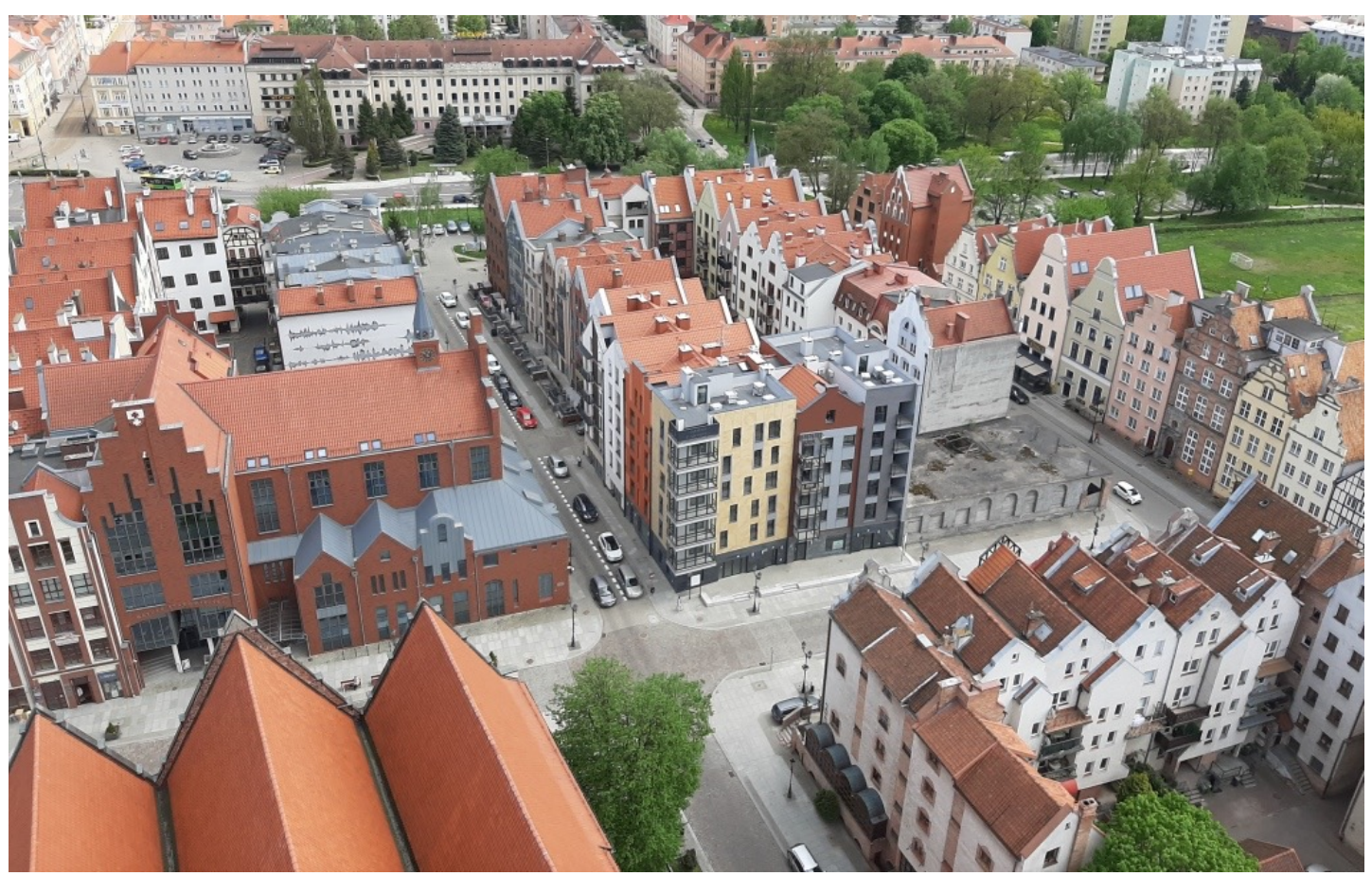

Ryc. 23. Ulica Stary Rynek i Rzeźnicka - przykłady realizacji metodą retrowersji z XX i XXI wieku. Fot. K. Wiśniewska

Choć przy każdej realizacji kamienicy czy kwartału zabudowy na Starym Mieście ustanowione w 1997 roku prawo miejscowe jest na nowo interpretowane, wydaje się, że jedyną słuszną koncepcją jest konsekwentne zakończenie rozpoczętego procesu odbudowy w obecnej formule, nieszukanie nowych zasad. Celowe jest natomiast nazwanie faz tego procesu dla uporządkowania chronologii myśli i wydarzeń, jeżeli uznajemy, że etap retrowersji zakończył się wraz z powstaniem parkingów podziemnych i zaniechaniem podziału funkcjonalnego poszczególnych kamienic i nastąpiła budowa Nówki Starówki.

\section{Podsumowanie}

Pogląd, że architektura jest pochodną całej tej historii, a nie punktem wyjścia, umacnia wiarę w „mit odbudowy” (Bugalski, 2014). Z takiej perspektywy krytyka współczesnej architektury na nowym Starym Mieście jest wyrazem tęsknoty za utraconą tożsamością, a nie dowodem na błędy taktyczne i merytoryczne przy kontynuowaniu rozpoczętego prawie czterdzieści lat temu procesu odbudowy, który musi dostosować się do zmieniającej się rzeczywistości i współczesności. W moim odczuciu w Elblągu mit odbudowy metodą retrowersji ewaluował do mitu odbudowy w duchu retrowersji. 
Patrząc z lotu ptaka, czy spacerując ulicami Starego Miasta w Elblągu, bez wątpienia można potwierdzić, że zaaranżowane zostało „nowe stare miasto” i wykreowany zbiór wartości utożsamianych $\mathrm{z}$ atmosferą zespołów staromiejskich.
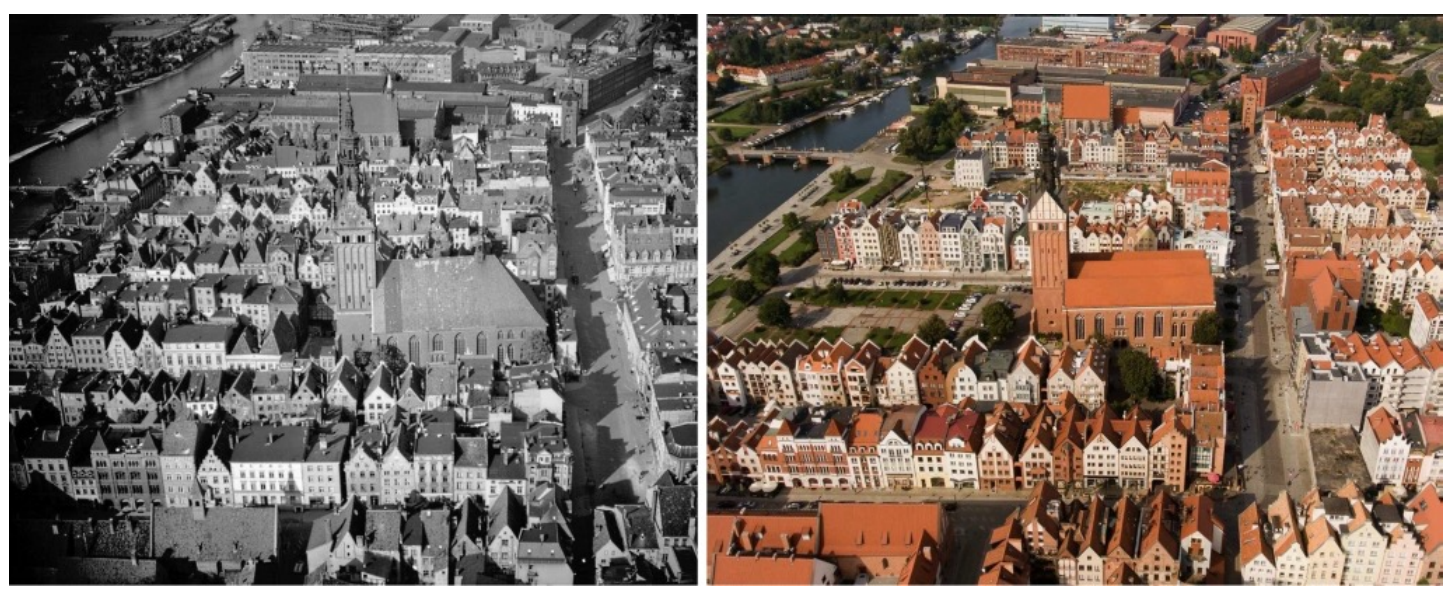

Ryc. 24 Stare Miasto w Elblągu rok 1922 i 2020. Źródło: Registratura Departamentu Urbanistyki i Architektury UM w Elblągu

Elbląg to miasto o niezwykłej tożsamości, której twarza staje się dziś elblaska Nówka Starówka, spektakularna $i$ unikalna $w$ wymiarze międzynarodowym retrowersja, czyli oryginalnie odbudowane, dawne, średniowieczne centrum miasta zburzone w czasie II wojny światowej. Nówka Starówka symbolizuje elblaski upór $w$ dą̇eniu do celu, jest niepowtarzalna emanacją elblaskiej przedsiębiorczości i wyjątkowej estetyki miasta. Architektonicznie - dzisiejszy Elblag - jest jednym $z$ najciekawszych miast $w$ Europie. Powstała $w$ Elblagu oryginalna, zaskakujaca i fascynująca przestrzeń publiczna to miejsce, do którego przenosi się dziś "prawdziwe życie” lokalnej społeczności $i^{8}$.

8 Studium Rozwoju Marki Elbląg 2020+. 


\section{Katarzyna Wiśniewska}

\section{Bibliografia}

Anders W., Odbudowa Starego Miasta w Elblagu - przywracanie ładu przestrzennego z uwzględnieniem rodzinnej struktury zabudowy. Elbląg, 1994.

Anders W., Przywracanie ładu przestrzennego zabytkowego miasta na przykładzie miasta Elbląga. Architektura nr 30. Wydawnictwo Politechniki Gdańskiej, Gdańsk, 1996.

Bugalski Ł., Kwestia odbudowy zabytkowych zespołów staromiejskich na ziemiach odzyskanych. Poznań: Przegląd Zachodni, 2014.

Jonakowski M., Odbudowa Starego Miasta w Elblagu - założenia konserwatorskie a rzeczywistość inwestycyjna - próba oceny. Warszawa: Registratura Departamentu Urbanistyki i Architektury w Urzędzie Miejskim w Elblągu, 2007.

Lubocka-Hoffmann M., Elbląg Stare Miasto. Elbląg: Państwowa Służba Ochrony Zabytków - Oficyna Wyd. Excalibur, 1998.

Studium programu $i$ wytycznych do przestrzennego uksztaltowania zabudowy Starego Miasta jako elementu śródmieścia Elblaga, Anders, W. (red.). Gdańsk: SARP Oddział Gdańsk - Wybrzeże, 1975.

Wiśniewska K., Elblag od strony rzeki mógłby wyglądać zupełnie inaczej - studium przypadku. Warszawa: Studia PAN KPZK, tom CLXXXVIII, 2018. 